\title{
A szívinfarktus prehospitális ideje a lakosság oktatásával és a mentőszolgálat gyorsabb igénybevételével csökkenthető
}

\author{
Dani Győző', Jambrik Zoltán², Márk László \\ ${ }^{1}$ Városi Kórház, Orosháza \\ ²Békés Megyei Központi Kórház, Pándy Kálmán Tagkórháza, Gyula \\ Levelezési cím: \\ Dr. Dani Győző, e-mail: danigyozo@gmail.com
}

Bevezetés: ST-elevációval járó szívizominfarktusban a későbbi kimenetel számára meghatározó teljes iszkémiás idő nagysága nagymértékben függ a betegek késlekedésétöl.

Célkitűzés: Saját régiónkban annak felmérése, hogy milyen tényezők befolyásolják betegeink döntéseit és a prehospitális ellátás hosszát.

Módszerek: A Békés Megyei Központi Kórház Invazív Kardiológiai Részlegén 2015. december 1. és 2016. december 31. között 145 akut ST-elevációs szívizominfarktuson átesett beteg adatait vizsgáltuk. Kérdöívben rögzítettük a prehospitális és kórházi kezelés időtartamait, illetve kérdéseket tettünk fel a beteg panaszainak jellegére, erősségére, a helyszíni ellátásra, illetve a betegek szívinfarktussal kapcsolatos megelőző ismereteire vonatkozóan.

Eredmények: A beteg késlekedési idő mediánja 100 (30-240) perc volt, a tejes iszkémiás idő 220 (126-421) perc. Ellátási területünk betegein 34,5\% volt azoknak az aránya, akik panaszaik jelentkezésekor a mentőszolgálat segítségét kérték, az NSZR adatai szerint ez az arány országosan $54,8 \%$. Amennyiben a primer ellátó a mentőszolgálat volt, a teljes iszkémiás idő szignifikánsan rövidebb volt (166 [105-267] vs. 240 [150-490] perc, p=0,001). A betegek panaszainak jellege és erőssége befolyásolta az egészségügyi ellátáshoz fordulás idejét.

Következtetések: Az ST-elevációs szívizominfarktus prehospitális ellátási ideje rövidebb, amennyiben a mentőszolgálat az első ellátó (mentők primer hívása gyakoribbá válásában a lakosság és a betegek oktatásának lehet szerepe), és ha erősebb a mellkasi fájdalom.

Kulcsszavak: ST-elevációs szívizominfarktus, teljes iszkémiás idő, prehospitális ellátás

Prehospital delay in myocardial infarction could be shortened by community education and by alerting emergency medical services in a more timely fashion

Introduction: The magnitude of total ischemic time determines the outcome of patients with ST-segment elevation myocardial infarction (STEMI) and is highly dependent on the delay of the patients themselves.

Objective: To assess what factors influence patient decision making and the length of pre-hospital care in our own region. Methods: We examined 145 patients with STEMI at the Invasive Cardiology Department of Békés County Central Hospital between 1 December 2015 and 31 December, 2016. We recorded the duration of pre-hospital and hospital treatment. We designed a questionnaire to assess the nature and strength of patient complaints related to seeking medical assistance, onsite care and former patient knowledge about myocardial infarction.

Results: The median delay time for patients was 100 (30-240) minutes, and the total ischemic time was 220 (126-421) minutes. The rate of patients turning directly to the National Ambulance Service for help was $34.5 \%$ in our region, while it was $54.8 \%$ according to the data Hungarian Myocardial Infarction Registry. If the primary care provider was the ambulance service, the total ischemic time was significantly shorter (166 [105-267] vs. 240 [150-490] minutes, $p=0.001)$. The nature and severity of patients'complaints influenced the time to seek health care.

Conclusions: Pre-hospital delay in ST elevation myocardial infarction is shorter if the ambulance service is the first provider (which can be facilitated by the education of the population and patients) and in the case of stronger chest pain.

Keywords: ST elevation myocardial infarction, total ischemic time, prehospital care 
A szívinfarktust elszenvedett betegek hosszú távú életkilátásait nagymértékben befolyásolja a revaszkularizációig eltelt idő. Hazai adatok alapján Jánosi és munkatársai is a teljes iszkémiás idő (az ST-elevációval járó szívizominfarktusban a panasz kezdetétől az ér megnyitásáig eltelt idő-TIT: teljes iszkémiás idő) prognosztikus jelentőségét hangsúlyozták a Nemzeti Szívinfarktus Regiszter (NSZR) adatai alapján (1). Ugyanakkor azt is megállapították, hogy a panasz kezdetétől az ér megnyitásáig eltelt idő nagy része a prehospitális időszakra esik (2). Ebben pedig nagy szerepe van a betegek késlekedésének. Több vizsgálat is foglalkozott azzal, hogy milyen tényezők befolyásolják szívizominfarktus esetén a betegek egészségügyi ellátáshoz fordulását, illetve a prehospitális időket (3). Az NSZR adatai is utalnak arra, hogy a revaszkularizáció optimális idejét nagymértékben befolyásolja az, hogy a betegek mikor kérnek segítséget az ellátószemélyzettől. Munkánkban arra a kérdésre kerestük a választ, hogy saját betegeink esetében, az ország délkeleti területén, Békés megyében a beteg panaszai, előzetes ismeretei, illetve az első ellátószemélyzet befolyásolták-e a prehospitális idő alakulását.

\section{Betegek és módszer}

A Békés Megyei Központi Kórház Invazív Kardiológiai Részlegén 2015. december 1. - 2016. december 31. között akut ST-elevációs szívizominfarktuson átesett betegek adatait vizsgáltuk. 145 beteg töltötte ki és válaszolt kórházi kezelése idején a kérdőíves felmérésben feltett kérdésekre. Kérdőívben rögzítettük (illetve az NSZR adatbázisával egyeztettük) a prehospitális és kórházi kezelés időtartamait (panaszkezdet ideje, egészségügyi ellátószemélyzet hívási ideje, mentő értesítési ideje, illetve a mentési ellátási idők, a kórházba érkezés ideje, az ér megnyitásáig eltelt idő). Kérdéseket tettünk fel a beteg panaszainak jellegére, erősségére. Emellett vizsgáltuk a beteg megelőző ismereteit az infarktussal kapcsolatban. Megvizsgáltuk a beteg, illetve a helyszíni ellátás során alkalmazott terápiát is. A betegadatainkat ezt követően a TIT függvényében elemzésnek vetettük alá, Jánosi és munkatársai közleménye alapján 200 percen belüli, illetve 400 percen túli TIT-csoportot hasonlítottuk össze, illetve összehasonlítottuk a betegelhatározási időket és a TIT abszolút értékeit is.

A statisztikai számításokat SPSS ver. 21 programmal végeztük. Leíró statisztikai jellemzőket a kategóriaváltozók esetén gyakoriság, folytonos változók esetében normális eloszlás esetén átlag (szórás), nem normál eloszlás esetén medián (kvartilisek) formájában adtuk meg. A vizsgált betegcsoportok közötti különbségek jellemzésére a folytonos változóknál Wilcoxon-illetve Kruskal-Wallis-próbát, a kategóriaváltozóknál khi-négyzet próbát alkalmaztunk.

\section{Eredmények}

Elemzésünkben 145, akut ST-elevációs miokardiális infarktuson átesett beteg vett részt, 110 férfi, 35 nő. $A z$

\begin{tabular}{|c|c|c|c|c|c|c|c|}
\hline & & $\begin{array}{l}\text { Betegek } \\
\text { száma (fö) }\end{array}$ & $\begin{array}{c}\text { Betegkésleke- } \\
\text { dési idó (medián } \\
\text { perc és (Q1, Q3 } \\
\text { kvartilisek) }\end{array}$ & $\begin{array}{l}\text { TTI (medián } \\
\text { perc és (Q1, Q3 } \\
\text { kvartilisek) }\end{array}$ & $\begin{array}{l}\text { TIT }<200 \\
\text { perc (fö) }\end{array}$ & $\begin{array}{c}\text { TIT } \\
200-400 \\
\text { perc (fö) }\end{array}$ & $\begin{array}{c}\text { TIT >400 } \\
\text { perc } \\
\text { (fö) }\end{array}$ \\
\hline \multicolumn{2}{|l|}{ Összes beteg } & 145 & $100(30-240)$ & $220(126-421)$ & 38 & 69 & 38 \\
\hline \multirow{2}{*}{ Nem } & Férfi & 110 & $99(30-240)$ & 208 (123-389) & 30 & 53 & 27 \\
\hline & Nő & 35 & $120(40-270)$ & $262(132-432)$ & 8 & 16 & 11 \\
\hline \multirow{2}{*}{ Foglalkozás } & Aktív & 62 & $97,5(30-259,5)$ & $202(123,7-450)$ & 17 & 29 & 16 \\
\hline & Nyugdíjas & 83 & $110(40-225)$ & $240(130-410)$ & 21 & 40 & 22 \\
\hline \multirow{3}{*}{ Végzettség } & $\begin{array}{l}\text { Általános } \\
\text { iskola }\end{array}$ & 58 & $110(30-315)$ & $260(131,3-476,3)$ & 14 & 25 & 19 \\
\hline & Középiskola & 73 & $104(40-208,5)$ & $210(129,5-360)$ & 18 & 40 & 15 \\
\hline & $\begin{array}{l}\text { Egyetem/ } \\
\text { fóiskola }\end{array}$ & 14 & $35(8,75-150)$ & $164,5(85-427,5)$ & 6 & 4 & 4 \\
\hline \multirow{3}{*}{$\begin{array}{l}\text { Dohányzási } \\
\text { szokások }\end{array}$} & Igen & 72 & $75(30-150)$ & $205(127-264)$ & 18 & 41 & 13 \\
\hline & Nem & 55 & $150(37-330)$ & $302(115-490)$ & 15 & 20 & 20 \\
\hline & Leszokott & 18 & $88(27,5-352)$ & $188(124,5-594,8)$ & 5 & 8 & 5 \\
\hline \multirow{2}{*}{$\begin{array}{l}\text { Korábbi szív- } \\
\text { izominfarktus }\end{array}$} & Igen & 27 & $105(40-240)$ & $180(150-372)$ & 6 & 15 & 6 \\
\hline & Nem & 115 & $95(30-210)$ & $230(125-410)$ & 32 & 53 & 30 \\
\hline \multirow{3}{*}{ Infarktus ideje } & 07:00-15:00 & 66 & $110(38,5-380)$ & $232(122,5-486)$ & 17 & 28 & 21 \\
\hline & $15: 00-23: 00$ & 55 & $70(30-197,3)$ & $201(117-381)$ & 18 & 25 & 12 \\
\hline & 23:00-07:00 & 24 & $147(62,5-207,5)$ & $227(167,8-328,8)$ & 3 & 16 & 5 \\
\hline
\end{tabular}


2. TÁBLÁZAT. Betegeink szívizominfarktusról és ellátásáról szerzett ismeretei

\section{Betegek száma (fö)}

Milyen forrásból hallotta, hogy a szívinfarktus életveszélyes betegség?

\begin{tabular}{l|c}
\hline Rokon & 52 \\
\hline Barát & 37 \\
\hline Munkatárs & 14 \\
\hline Egészségügyi dolgozó & 27 \\
\hline Internet & 24 \\
\hline Média & 4 \\
\hline Egyéb & 7 \\
\hline Tudta, hogy az OMSZ képes ellátni & \\
\hline a szívizominfarktust? & \\
\hline Igen & $49(33,8 \%)$ \\
\hline Nem & $96(66,2 \%)$
\end{tabular}

Tudta, hogy minél gyorsabban kap ellátást, annál nagyobb a gyógyulás esélye?
Igen
$114(78,6 \%)$
Nem
31

átlagéletkor 63,1 111,0 év volt. A betegeink demográfiai adatait összefoglaltuk az 1. táblázatban. Illetve ebben a táblázatban hasonlítottuk össze a betegek panaszkezdetétől a mentő, illetve az egészségügyi személyzet igénybevételéig eltelt időt (beteg késlekedési idő) és a TIT-t. Ezen idők szerepelnek alcsoportonkénti bontásban is. Nem találtunk szignifikáns különbséget egyik csoport között sem. Bár nők esetében az elhatározá- si idő hosszabb volt, mint férfiaknál, a nőbetegek csak az összes beteg negyedét adták (24,1\%). Továbbá nem találtunk szignifikáns különbséget a foglalkozás, iskolai végzettség, dohányzási szokások, illetve az infarktus ideje szerint sem.

Megvizsgáltuk emellett kérdőívünkben azt is, hogy betegeink rendelkeztek-e előzőleg ismeretekkel a szívizominfarktusról, illetve ezen ismeretek milyen forrásból származtak. Ezeket az adatokat a 2. táblázatban foglaltuk össze. A betegek kivétel nélkül tudták, hogy a szívizominfarktus életveszélyes betegség, jórészt személyes tapasztalat, hallomás útján (rokon, barát, munkatárs). Azzal is tisztában volt a betegek 78\%-a, hogy minél hamarabb, gyorsabban kell ellátni a szívizominfarktust, azonban csak 1/3-uk volt tisztában azzal, hogy a mentőszolgálat is képes már az infarktus kezdetekor elindítani a megfelelő kezelést.

A 3. táblázat a betegek panaszait a késlekedési idő és a TIT függvényében mutatja be. Tekintettel a panaszok megfogalmazásában, szubjektív érzésében és a betegek által történt leírásában észlelhető nagy különbségekre, igyekeztünk kérdésekkel irányítani a panaszok jellegére adott válaszokat. Szubjektív panaszként két fő kategóriát határoztunk meg. Az egyik a hirtelen, erős, késszúrásszerủ fájdalom, a másik fő típus pedig a tompa, nyomó mellkasi fájdalom volt. Amennyiben nem ilyen jelleggel élte meg a panaszait a beteg, egyebet jelölhetett meg. Itt mind a beteg elhatározási időkben, mind a TIT-ben különbséget láttunk, a hirtelen erős, késszúrásszerü fájdalom esetén a betegek kevesebbet vártak, a TIT lerövidült. A többi kísérő tünet és panasz

\section{TÁBLÁZAT. A szívinfarktus felléptekor érzett panaszok jellemzése a TIT függvényében}

\begin{tabular}{|c|c|c|c|c|c|c|}
\hline & $\begin{array}{l}\text { Betegek } \\
\text { száma (fö) }\end{array}$ & $\begin{array}{c}\text { Betegkés- } \\
\text { lekedési idő } \\
\text { (medián perc } \\
\text { és (Q1, Q3 } \\
\text { kvartilisek) }\end{array}$ & $\begin{array}{l}\text { TTI (medián } \\
\text { perc és (Q1, Q3 } \\
\text { kvartilisek) }\end{array}$ & $\begin{array}{l}\text { TIT } \\
<200 \\
\text { perc } \\
\text { (fö) }\end{array}$ & $\begin{array}{c}\text { TIT } \\
200- \\
400 \\
\text { perc } \\
\text { (fö) }\end{array}$ & $\begin{array}{l}\text { TIT } \\
>400 \\
\text { perc } \\
\text { (fó) }\end{array}$ \\
\hline \multicolumn{7}{|l|}{ Fájdalom jellege } \\
\hline Hirtelen éles, késszúrásszerü & 43 & $80(30-150)$ & $160(100-230)$ & 18 & 23 & 2 \\
\hline Tompa, nyomó & 87 & $110(40-230)$ & $243(147-511)$ & 18 & 38 & 31 \\
\hline
\end{tabular}

Hirtelen, éles vs. tompa, nyomó fájdalom $(p<0,05)$

\begin{tabular}{|c|c|c|c|c|c|}
\hline Égető & 15 & & 6 & 5 & 4 \\
\hline Zsibbadás & 35 & & 10 & 17 & 8 \\
\hline Köhögés & 7 & & 1 & 5 & 1 \\
\hline \multicolumn{6}{|l|}{ Szédülés } \\
\hline Eszméletvesztés & 3 & & 1 & 2 & 0 \\
\hline Légszomj & 24 & & 6 & 13 & 5 \\
\hline Szorongás & 17 & & 1 & 13 & 3 \\
\hline Halálfélelem & 10 & & 2 & 6 & 2 \\
\hline \multicolumn{6}{|l|}{ Verejtékezés } \\
\hline Hányinger/hányás & 36 & & 6 & 17 & 13 \\
\hline Gyomortáji fájdalom & 25 & & 7 & 14 & 4 \\
\hline Fájdalom erőssége & 7,55 & $p=0,076$ & 8,05 & 7,44 & 7,26 \\
\hline
\end{tabular}


4. TÁBLÁZAT. A segélyhívás és az első ellátás kapcsán szerzett információink összefoglalása

\begin{tabular}{|c|c|c|c|c|c|}
\hline $\begin{array}{l}\text { Betegek } \\
\text { száma (fö) }\end{array}$ & $\begin{array}{l}\text { Betegkéslekedési } \\
\text { idő (medián perc és } \\
\text { (Q1, Q3 kvartilisek) }\end{array}$ & $\begin{array}{l}\text { TTI (medián } \\
\text { perc és (Q1, Q3 } \\
\text { kvartilisek) }\end{array}$ & $\begin{array}{c}\text { TIT } \\
<200 \text { perc } \\
\text { (fö) }\end{array}$ & $\begin{array}{c}\text { TIT } \\
200-400 \\
\text { perc (fö) }\end{array}$ & $\begin{array}{l}\text { TIT >400 } \\
\text { perc (fö) }\end{array}$ \\
\hline
\end{tabular}

Gondolt-e szívizominfarktusra?

\begin{tabular}{|c|c|c|c|c|c|c|}
\hline Igen & 78 & $93(30-210)$ & $209(116-350)$ & 22 & 39 & 17 \\
\hline Nem & 67 & 115 (55-320) & $249(133-464)$ & 16 & 30 & 21 \\
\hline
\end{tabular}

Vett-e magától gyógyszert, hogy szűnjön a panasz?

\begin{tabular}{|c|c|c|c|c|c|c|}
\hline Igen & 43 & $120(40-341)$ & $262(170-480)$ & 3 & 24 & 16 \\
\hline Nem & 96 & $90(30-201)$ & $200(108-349)$ & 34 & 42 & 20 \\
\hline \multicolumn{7}{|c|}{ Kitöl kért segítséget? } \\
\hline Ügyelet/háziorvos & 95 & $120(45-330)$ & $240(150-490)$ & 18 & 45 & 32 \\
\hline \multirow[t]{2}{*}{ OMSZ/SBO } & 50 & $60(20-186)$ & $166(105-267)$ & 20 & 24 & 6 \\
\hline & & & $p=0,017$ & $p=0,001$ & $p=0,001$ & \\
\hline \multicolumn{7}{|c|}{ Ki végzett EKG-t az első ellátáskor? } \\
\hline Ügyelet/ háziorvos & 26 & $130(52-408)$ & $294(150-519)$ & 3 & 13 & 10 \\
\hline OMSZ/SBO & 95 & $95(30-200)$ & $217(120-350)$ & 24 & 43 & 28 \\
\hline
\end{tabular}

gyakorisága (eszméletvesztés, hányinger, hányás, szédülés stb.) nem minden betegnél és jóval ritkábban fordultak elő. Vizsgáltuk a fájdalom erősségét is, amelyet a betegek 1-10-ig tartó vizuális skálán adtak meg. Eredményeinkből látható, hogy a panaszok kezdetén érzett fájdalom erőssége fordítottan volt arányos a TIT nagyságával, de az összefüggés nem volt szignifikáns mértékü.

Felmértük a helyszínen történt ellátást is (4. táblázat). Betegeink 34,5\%-a fordult panaszaik jelentkezésekor egyből a mentőszolgálathoz. Ez lényegesen alacsonyabb az NSZR adatai szerinti országos 54,8\%-nál. Azon betegeinkben, akik egyből a mentőszolgálathoz, illetve SBO-hoz fordultak, szignifikánsan rövidebb volt az elhatározási idő és a TIT. Ugyanakkor azt is megállapítottuk, hogy a betegek nagy része ügyelethez, háziorvoshoz fordult panaszával (65\%), az első rögzített panaszos EKG-görbék csak 17\%-a készült a háziorvos/ ügyeletes orvos által. A többi esetben az EKG-görbe rögzítése később, csak a mentőszállítás alatt, illetve esetleg csak az SBO-n történt meg.

\section{Megbeszélés}

A szívizominfarktus kimenetelét nagymértékben meghatározza az elhalt szívizom nagysága, ennek mértéke pedig jelentősen függ az elzáródás, az iszkémia fennállásának hosszától (TIT). Vizsgálatunkban válaszokat kerestünk arra a kérdésre, hogy Magyarországon és szükebb régiónkban is miért olyan hosszú a TIT. Ez az időintervallum több részidőből adódik össze, a gyakorlatban a panasz felléptétől az elzárt ér megnyitásáig tartó időt jelenti. Több tanulmány hangsúlyozza, hogy a TIT a leghosszabb és ezért talán legfontosabb összetevője a prehospitális késés. Ugyanakkor ennek nagysá- gán évtizedek alatt sem sikerült lényegesen csökkenteni. Részben ennek oka az egészségügyi ellátástól független, elsősorban a betegeken múló tényezők miatt jön létre. Ez az úgynevezett döntési idő, a beteg késlekedéséből származó időveszteség. Emellett a beteg döntése a primer ellátás megválasztása útján is befolyásolja a kórházba kerülés időtartamát, a prehospitális időt. Egy kínai felmérésben számos tényező szerepét vetették fel a prehospitális késés okaként, az életkor, a nem, a szociális helyzet mellett a panaszok felléptének időpontját is (4). Emellett az NSZR adatai alapján számos elemzés született, és saját magunk is próbáltuk tanulmányozni szükebb régiónkban a prehospitális infarktusellátást.

Korábbi vizsgálatunkban felmértük 25 év elteltével a prehospitális idők alakulását 2011 júliusa és 2013 júniusa közötti két év időszakát összehasonlítva az 1985ben történt felmérésünkkel $(5,6)$. A 2011-ben végzett felmérés idején, Gyulán még nem müködött Invazív Kardiológia Részleg, ezért nem szerepeltek benne az akkori területileg illetékes szegedi primer ellátóhelyen a gyulai kórház érintése nélkül ellátott betegek. Ekkor STEMI-s betegeink körében az elhatározási idő mediánja 30 perc volt. Jelen vizsgálatunkban ez 100 percnek adódott. Ez a jelentős különbség részben annak köszönhető, hogy itt speciális betegcsoport szerepelt, akik egyből a gyulai kórházban jelentkeztek panaszaikkal, nem befolyásolta őket a mentőszolgálat vagy egyéb egészségügyi személyzet hívásának gondja és nem szerepeltek ezen felmérésben a mentőszolgálat által akkor közvetlenül a szegedi Invazív Kardiológiára szállított betegek sem. Ugyanakkor jelen felmérésünkben észlelt időablakok megegyeznek Jánosi és munkatársai által publikált vizsgálatban a Nemzeti Szívinfarktus Regiszter adatai alapján a Békés megyében észlelt 96,5 perc medián elhatározási idővel (7). A TIT tekinte- 
tében pedig 210 perc volt ez az idő, a mi anyagunkban 220 perc. Látható, hogy a TIT felét a beteg elhatározása és az ebből származó késlekedés teszi ki, de a transzport idejének rövidítésével is csökkenthető a TIT nagysága. Részben ez a hosszú idő annak is köszönhető, hogy a betegek nem a primer szállító és a megfelelő ellátást nyújtó mentőszolgálathoz fordulnak segítségért, hanem zömében (a vizsgálatunkban az esetek 2/3-ában) a családorvost vagy az ügyeleti ellátást keresik fel először. Eredményeink azt is alátámasztják, hogy az elsődlegesen mentőszolgálathoz fordult betegek esetében a TIT értéke szignifikánsan rövidebb, bár ebben szerepet játszik az is, hogy rövidebb a betegek elhatározási ideje is. Az egészségügyi személyzet megérkezte utáni ellátást nehezíti és rontja az is, hogy bár a primer ellátók gyakrabban a családorvosok, illetve ügyeleti orvosok, mégis az esetek csak kis részében történik EKG-vizsgálat ezen esetekben. Nem tartjuk elfogadhatónak, hogy ezen első ellátóhelyen csak a betegek 17\%-ának csináltak EKG-t. A helyszínen készült EKG segítené a mentésirányítás munkáját is, biztosíthatná a megfelelő betegellátást és monitorozást biztosító mentő gépkocsi biztosítását, illetve a felesleges primer ellátóhelyek közbeiktatását. Megyénkben a panaszok jelentkezésekor mentőt hívók 34,5\%-os aránya lényegesen alatta van az 54,8\%-os országos átlagnak. Az első egészségügyi ellátás idejét egyes vizsgálatokban eltérően értelmezik, az egészségügyi személyzet hívását, az ellátószemélyzet helyszínre érkezését és az EKG-készítés időpontját is figyelembe vehetjük. Ugyanakkor az EKG-során látott ST-eleváció biztosítja a panaszokkal együtt a STEMI diagnózisát, ezért az EKG mihamarabbi elkészítése rövidíti az ellátás idejét (8), ezért a betegek oktatásában fontos lenne hangsúlyozni, hogy a panasz felléptekor minél hamarabb EKG készüljön. Ennek gyors biztosítására pedig a jól felszerelt és szakképzett mentőszemélyzet alkalmas. Vizsgálatunkban csak a betegek harmada tudta, hogy a mentőszolgálat a panaszok kezdetekor indíthat megfelelő kezelést.

McKee és munkatársai többváltozós elemzésükben a mentőszolgálat alkalmazásával és a panaszok erősségével és hirtelen megjelenésével együtt észlelték a prehospitális idő csökkenését (9). Ugyanakkor randomizált vizsgálatban a betegek oktatásával nem sikerült elérni a késési idő csökkenését (10).

A lakosság és a betegek edukációja csökkenthetné a TTI-t azzal is, hogy a több ismeret birtokában hamarabb felismerik a saját vagy a hozzátartozóik tüneteiben a kardiális okot és ezzel hamarabb kérnek egészségügyi segítséget és ezzel gyorsabban kerülnek EKG-készítés közelébe, de McKee vizsgálatában a családorvos felkeresése hosszabbította a prehospitális időt (9) és a randomizált amerikai vizsgálat sem igazolta az oktatás ez irányú hasznát (10). Ebből nem kell következtetnünk, hogy maga a betegedukáció haszontalan. Az oktatásban mindenképpen a gyors, mihamarabbi mentőhívás előnyeit kell hangsúlyozni. (Az alapvető egészségügyi ismeretek javítására egyébként is szükség lenne nálunk.)

A betegek részéről a panaszok erőssége és jellege nagymértékben meghatározza, hogy mikor fordulnak sürgősen orvoshoz. Több mint két évtizede már megvizsgáltuk a betegek által elmondott, a tünetek jelentkezésekor észlelt panaszokat, ezeket jelen kérdőívünk megszerkesztésében is figyelembe vettük $(11,12)$. Vizsgálati anyagunkban az éles, hirtelen, szúró fájdalmat ijesztőbbnek ítélték meg a betegek, hamarabb kértek segítséget. Emellett a fájdalom erőssége is befolyásolja a prehospitális időt. Hudzik Lengyelországban végzett vizsgálatában azt találta, hogy bár a betegek 73,8\%-a infarktus következményének tartja a mellkasi fájdalmát, csak 23\%-ban szólnak rögtön a panasz kialakulásakor, 31,7\%-ban várnak 3-4 órát (13).

Bugiardini vizsgálatában a nők sokkal vulnerábilisabbnak bizonyultak a prehospitális késésre, nőknél a prehospitális idő szignifikánsan magasabb volt (14). Amennyiben azonban 1 órán belül megtörtént a reperfúzió, a különbség eltűnt. A mi vizsgálati anyagunkban is a nők esetében hosszabb volt az elhatározási idő, de ez nem volt szignifikáns mértékű, részben amiatt, hogy vizsgálatunkban csak a betegek negyede volt nő.

Nguyen és munkatársai 20 év távlatában 1986 és 2005 között a prehospitális időben jelentős változást nem tapasztaltak, a 65 év alatti férfiak csoportjában észlelték a legrövidebb prehospitális időt (15). Korábbi vizsgálatunkban több mint két évtizeddel ezelőtt vizsgáltuk az infarktus diurnális előfordulását. Jelen felmérésünkben nem találtunk összefüggést a panaszok kezdetének diurnális változása, illetve a TIT között kapcsolatot.

A TIT lerövidítésére, a prehospitális idő csökkentésére lehetőséget teremtene betegeink oktatása, a megfelelő betegutak kiválasztásának hangsúlyozása. Thorn és munkatársai a mentők direkt hívásának jelentőségét hangsúlyozták (16). Emellett többféle edukációs módszert próbáltak a gyakorlatban, változó sikerrel (17, 18, 19). Felmérésünk adatai alapján az derül ki, hogy betegeink nagyobb része hozzátartozók, rokonok, ismerősök útján szerzi be az információit. Ezért is fontos a mindennapi gyakorlatban az, hogy betegeinket minél jobban megismertessük elszenvedett betegségükkel. Ennek haszna abban is megnyilvánul, hogy saját betegségük hosszú távú kezelése, a szekunder prevenciós gyógyszerek alkalmazása és a megfelelő életmódváltás jobban elérhető. Fontos lehet továbbá az is, hogy a megszerzett ismereteket, például a mentőszolgálat kiemelkedően fontos szerepét - saját tapasztalatuk útján - át tudják adni hozzátartozóiknak, ismerőseiknek. Elemzésünk azt igazolta, hogy az erős fájdalom rövidebb prehospitális idővel járt együtt. A TIT rövidítésében a mentők mihamarabbi hívása a legfontosabb tényező, ezért azt gondoljuk, hogy a betegek oktatásában ezt hangsúlyozni kell. 


\section{Következtetések}

Vizsgálatunk korlátja, hogy csak Békés megyei betegeket vontunk be, de ez egyben egy erőssége is, mert annak a régiónak a jellemzőit mutatja meg. További korlát a kicsi esetszám, ugyanakkor az a tény, hogy csak egy centrumban történt, biztosítja, hogy az adatok felvétele azonos körülmények között zajlott. Az NSZR által igényelt adatbevételhez képest sokkal részletesebb kikérdezése történt a betegeknek. Adataink STEMI-s betegek esetén egyezést mutatnak az NSZR és az Országos Mentőszolgálat által találtakkal.

\section{Nyilatkozat}

A szerzők kijelentik, hogy a közlemény megírásával kapcsolatban nem áll fenn velük szemben pénzügyi vagy egyéb lényeges összeütközés, összeférhetetlenségi ok, amely befolyásolhatja a közleményben bemutatott eredményeket, az abból levont következtetéseket vagy azok értelmezését.

\section{Irodalom}

1. Jánosi A, Erdős G, Pach FP, et al. Prognostic significance of the total ischemic time in patients with ST-elevation myocardial infarction (A teljes ischaemiás idő prognosztikus jelentősége az ST-elevációval járó szívinfarktus miatt kezelt betegekben). Orv Hetil 2018; 159: 1113-1120. doi:10.1556/650.2018.31108 (Hungarian)

2. Jánosi $A$, Csató G, Pach FP, et al. Emergency care of patients with myocardial infarction: from the onset of symptoms until opening the vessel. (Szívinfarktus miatt kezelt betegek sürgősségi ellátása: a panasz kezdetétől az ér megnyitásáig). Orv Hetil 2020; 161: 458467. doi:10.1556/650.2020.31679 (Hungarian)

3. Gärtner C, Walz L, Bauernschmitt E, Ladwig KH. The causes of prehospital delay in myocardial infarction. Dtsch Arztebl Int 2008; 105: 286-291. doi:10.3238/arztebl.2008.0286

4. Feng L, Li M, Xie W, et al Prehospital and in-hospital delays to care and associated factors in patients with STEMI: an observational study in 101 non-PCI hospitals in China. BMJ Open 2019; 9: e031918. doi: 10.1136/bmjopen-2019-031918

5. Márk L, Dani Gy, Ruzsa J, et al. Has the length of prehospital time and diurnal fluctuation of the occurrence of AMI changed in the last 25 years in the catchment area of the hospital of Gyula? (Változott-e a szívinfarktus prehospitális ideje és kezdetének napszaki ingadozása az elmúlt negyed évszázadban a gyulai kórház ellátási területén?) Cardiol Hung 2015; 45: 253-257. (Hungarian)

6. Mark L, Dani G, Vendrey R, Ruzsa J, Katona A. Improvement in prehospital time in acute coronary syndrome between 1985 and 2013 in the south-eastern area of Hungary. Wien Klin Wochenschr 2015; 127: 218-221. doi: 10.1007/s00508-015-0717-7
7. Jánosi A, Csató G, Pach FP, et al. Analysis of pre-hospital delay time of patients with myocardial infarction. (Szívinfarktus miatt kezelt betegek prehospitális késési idejének elemzése) Orv Hetil 2019; 160: 20-25. (Hungarian) doi: 10.1556/650.2019.31253

8. Żurowska-Wolak M, Piekos P, Jąkała J, Mikos M. The effects of prehospital system delays on the treatment efficacy of STEMI patients. Scand J Trauma Resusc Emerg Med 2019; 27: 39. doi:10.1186/ s13049-019-0616-4

9. McKee G, Mooney M, O'Donnell S, el al. Multivariate analysis of predictors of pre-hospital delay in acute coronary syndrome. Int $J$ Cardiol 2013; 168: 2706-2713. doi:10.1016/j.ijcard.2013.03.022

10. Dracup K, McKinley S, Riegel B, et al. A randomized clinical trial to reduce patient prehospital delay to treatment in acute coronary syndrome. Circ Cardiovasc Qual Outcomes 2009; 2: 524-532. doi:10.1161/CIRCOUTCOMES.109.852608

11. Márk L, Deli L. Az acut myocardialis infarctus prehospitalis szakának vizsgálata kórházunk ellátási területén. Népegészségügy 1987; 68: 286-288.

12. Márk L, Deli L. A szívizominfarctus prodromalis tüneteiről. Cardiol Hung 1988; 17: 345-348.

13. Hudzik B, Korbel E, Popielarz B, et al. Patient prehospital delays in acute myocardial infarction. A nationwide patient survey. Heart attack-time is life campaign. L P1744 Eur Heart J October 2019; 40(Supplement_1): ehz748.0498, https://doi.org/10.1093/eurheartj/ ehz748.0498

14. Bugiardini R, Ricci B, Cenko E, et al. Delayed Care and Mortality Among Women and Men With Myocardial Infarction. J Am Heart Assoc 2017; 6(8): e005968. Published 2017 Aug 21. doi:10.1161/ JAHA.117.005968

15. Nguyen HL, Gore JM, Saczynski JS, et al. Age and sex differences and 20-year trends (1986 to 2005) in prehospital delay in patients hospitalized with acute myocardial infarction. Circ Cardiovasc Qual Outcomes 2010; 3(6): 590-598. doi:10.1161/CIRCOUTCOMES.110.957878

16. Thorn S, Attali P, Boulenc JM, et al. Délais de prise en charge de l'infarctus aigu du myocarde avec sus-décalage persistant du segment ST admis dans les USIC d'Alsace (Delays of treatment of acute myocardial infarction with ST elevation admitted to the CCU (coronary care unit) in Alsace). Arch Mal Coeur Vaiss 2007; 100(1): 7-12. 17. Bray JE, Stub D, Ngu P, et al. Mass Media Campaigns' Influence on Prehospital Behavior for Acute Coronary Syndromes: An Evaluation of the Australian Heart Foundation's Warning Signs Campaign. J Am Heart Assoc 2015; 4(7): e001927. Published 2015 Jul 6. doi:10.1161/JAHA.115.001927

18. Mooney M, McKee G, Fealy G, et al. A review of interventions aimed at reducing pre-hospital delay time in acute coronary syndrome: what has worked and why? Eur J Cardiovasc Nurs 2012; 11: 445-453. doi:10.1016/j.ejcnurse.2011.04.003

19. Garofalo D, Grey C, Lee M, et al. Pre-hospital delay in acute coronary syndromes: PREDICT CVD-18. N Z Med J 2012; 125(1348): 12-22. Published 2012 Jan 20. 